\title{
Leptin Affects Proliferation-, Apoptosis- and Protein Kinase A-Related Peptides in Human Ovarian Granulosa Cells
}

\author{
A. V. SIROTKIN ${ }^{1}$, M. MLYNČEK ${ }^{2}$, A. V. MAKAREVICH ${ }^{1}$, I. FLORKOVIČOVÁ ${ }^{1}$, \\ L. HETÉNYI ${ }^{1}$
}

${ }^{1}$ Research Institute of Animal Production and ${ }^{2}$ Hospital of Nitra, Nitra, Slovak Republic

Received November 7, 2006

Accepted December 19, 2006

On-line April 25, 2007

\begin{abstract}
Summary
The aim of our in vitro studies was to understand the role of leptin in controlling proliferation, apoptosis, and protein kinase $A$ (PKA) in human ovarian cells. We analyzed the in vitro effects of leptin $(0,1,10$ or $100 \mathrm{ng} / \mathrm{ml})$ on the accumulation of proliferation-related peptides (PCNA, cyclin B1), apoptosisassociated peptide (Bax) and the intracellular signaling molecule PKA in cultured human granulosa cells using immunocytochemistry and Western immunoblotting. It was observed that leptin stimulated in a dose-dependent manner the accumulation of PCNA (at doses 1-100 ng/ml), cyclin B1 (at doses 10 or $100 \mathrm{ng} / \mathrm{ml}$ ), Bax (at doses 10 or $100 \mathrm{ng} / \mathrm{ml}$ ) and PKA (at doses $1-100 \mathrm{ng} / \mathrm{ml}$ ) in cultured human ovarian cells. These observations suggest the ability of leptin to control directly human ovarian cell functions: proliferation, apoptosis, and intracellular messenger PKA.
\end{abstract}

\section{Key words}

Leptin $\bullet$ PCNA $\bullet$ Cyclin B $\bullet$ Bax $\bullet$ Protein kinase A $\bullet$ Ovary

\section{Corresponding author}

Alexander V. Sirotkin, Research Institute of Animal Production, Hlohovská 2, 94992 Nitra, Slovakia. Fax: +421-37-6546361. E-mail: sirotkin@scpv.sk

\section{Introduction}

Metabolic state can affect reproductive processes and induce some reproductive dysfunctions via alterations in production, reception, or response to leptin. This product of adipose tissue can control reproductive processes through hypothalamic LH-RH (Smith et al. 2001), although direct effects of leptin on the ovary has been documented (Spicer 2001). Leptin can affect ovarian steroidogenesis: stimulatory and inhibitory effects on the secretion of progesterone (P), androgens and estradiol (E) by cultured rat, bovine, porcine and human ovarian cells have been reported (Kitawaki et al. 1999, Almog et al. 2001, Ruiz-Cortez et al. 2003, Sirotkin et al. 2005), although such changes have not been found consistently (Agarwal et al. 1999, Spicer et al. 2000, Spicer 2001, Smith et al. 2001, Huang et al. 2002, Duggal et al. 2002, Ruiz-Cortez et al. 2003). In addition to steroidogenesis, the inhibitory action of leptin on prostaglandin $\mathrm{E}_{2}$ secretion by rat ovarian cells has been reported (Duggal et al. 2002). In human granulosa cells, leptin stimulated oxytocin, prostaglandin $\mathrm{F}$ and IGFBP-3 and suppressed IGF-I release (Sirotkin et al. 2005)

Effects of leptin on other ovarian functions (growth, proliferation and apoptosis) are uncertain. In vitro, leptin was able to inhibit the growth of ovarian follicles in mice (Kikuchi et al. 2001), although no effect on granulosa cell number in women (Huang et al. 2002), DNA synthesis in rats (Duggal et al. 2002) or cell death in pigs (Ruiz-Cortes et al. 2003) was observed. In vivo, leptin increased both pro-apoptotic (Bax) and antiapoptotic $(\mathrm{Bcl})$ peptides and the $\mathrm{Bcl} / \mathrm{Bax}$ ratio, resulting in suppression of ovarian cell apoptosis and promotion of puberty (rat: Almog et al. 2001). Furthermore, leptin deficiency in mice is associated with suppression of ovarian folliculogenesis and increase in ovarian granulosa cell apoptosis, but not in PCNA, marker of DNA replication/repair and of $\mathrm{S}$ phase of cell cycle (Hamm et al. 2004). No influence of leptin on markers of other phases of cell cycle (e.g. on cyclins, markers of $G$ phases) 
was reported yet. Therefore, the available data demonstrate both inhibitory and stimulatory effect of leptin on ovarian folliculogenesis and apoptosis, but no influence of leptin on marker of mitotic $\mathrm{S}$ phase/DNA replication was detected, whilst effect of leptin on markers of other phases of cell cycle has not been studied yet. Thus, the action of leptin on these processes requires further studies.

The effects of some hormones and growth factors on ovarian functions may be mediated by protein kinase A (PKA) and PKA-regulated transcription factors (Richards 2001). The stimulatory effect of leptin on tyrosine phosphorylation of STAT3 in human granulosa cells (Ruiz-Cortes et al. 2003) and mouse oocytes (Matsuoka et al. 1999) has been reported, but the relationship between leptin and other intracellular messengers, in particular PKA, in the ovary remains unknown.

Thus, the available information concerning leptin action on ovarian folliculogenesis and apoptosis is inconsistent, effect of leptin on ovarian cell cycle and PKA in the ovary has not yet been demonstrated.

The general aim of our in vitro experiments was to examine the effect of leptin on ovarian apoptosis, different phases of cell cycle and PKA. For this purpose, we examined the action of leptin on the expression of PCNA (marker of $\mathrm{S}$ phase of cell cycle), cyclin B1 (marker of $\mathrm{G}$ phase), Bax (marker of cytoplasmic apoptosis), and PKA within cultured human ovarian cells.

\section{Methods}

Preparation, culture, and processing of granulosa cells Isolation and processing of granulosa cells were performed as described previously (Sirotkin et al. 2005). Briefly, granulosa cells were harvested, 1-2 days after a spontaneous ovulation, from women 36-42 years of age with normal ovarian cycles and morphology who were undergoing ovariectomy because of non-metastatic cancer of the cervix uteri. The consent of the women was obtained in accordance with local ethical and medical regulations. Granulosa cells were aspirated from 2-6 mm diameter follicles, separated from follicular fluid by threefold centrifugation at $200 \mathrm{xg}$ for $10 \mathrm{~min}$ and washing in DMEM/Ham's F-12 1:1 mixture supplemented with $10 \%$ bovine fetal serum and $1 \%$ antibioticantimycotic solution (all from Sigma, St. Louis, USA). Cells were cultured in $2 \mathrm{ml}$ of this medium in Falcon 24-well plates (Becton Dickinson, Lincoln Park, USA) and Lab-Tek chamber slides (Nunc Inc., Naperville, USA) at $0.5 \times 10^{6}$ cells $/ \mathrm{ml}$ (determined by hemocytometer), at $37{ }^{\circ} \mathrm{C}$ under $5 \% \mathrm{CO}_{2}$ in humidified air. After 4 days of preculture, the medium was replaced with fresh medium of the same composition. Experimental groups were treated with biological grade recombinant human leptin $(0,1,10$, or $100 \mathrm{ng} / \mathrm{ml})$. The efficiency and physiological relevancy of these doses of leptin were demonstrated previously on ovarian cells (Agarwal et al. 1999, Kitawaki et al. 1999, Almog et al. 2001, Spicer et al. 2000, Kikuchi et al. 2001, Spicer 2001, Smith et al. 2001, Huang et al. 2002, Duggal et al. 2002, Ruiz-Cortez et al. 2003). Leptin was dissolved in culture medium immediately before experiment. Control groups were represented by cell-free (blank) medium or by cells cultured in medium with no exogenous leptin. After 2-day culture, the cell monolayer formed in culture plates was lysed by 3 cycles of freezing-thawing and vigorous pipetting in ice-cold electrophoretic buffer $(0.0625 \mathrm{M}$ Tris-base, $2 \%$ SDS, $10 \%$ glycerol, $0.5 \%$ 2-mercaptoethanol, $0.003 \%$ bromophenol blue, all from Sigma, $25 \mu \mathrm{l} / \mathrm{sample})$. The supernatant was separated from cellular membranes by centrifugation for $10 \mathrm{~min}$ at $200 x \mathrm{~g}$ and frozen at $-18{ }^{\circ} \mathrm{C}$ to await electrophoresis and immunoblotting. Chamber slides were washed three times in ice-cold PBS, fixed 20 min in $4 \%$ paraformaldehyde in PBS, washed in PBS ( $2 \times 5 \mathrm{~min})$, ethanol (70\%: $5 \mathrm{~min}, 80 \%$ : $10 \mathrm{~min}, 96 \%$ : $2 \times 10 \mathrm{~min}, 100 \%$ : $10 \mathrm{~min}$ ) and kept in $100 \%$ ethanol at $-22{ }^{\circ} \mathrm{C}$ to await immunocytochemical analysis. After culture, before lysis and fixation, cell concentration and viability were determined by Trypan blue staining and counting on hemocytometer. No statistically significant differences in these indices were observed between the groups.

\section{Immunocytochemical analysis}

The intracellular proliferation-associated and signalling substances were detected in granulosa cells plated on chamber-slides, using immunocytochemistry (Osborn and Isenberg 1994). ImmunoCruz Staining System and primary rabbit polyclonal antibodies against the human PCNA (cross-reacts with mouse, rat, human, insect and yeast full-length PCNA), human PKA (crossreacts with type I beta regulatory subunit and partially with I- $\alpha$ catalytic subunit of human, mouse, rat, bovine and porcine PKA), or mouse monoclonal antibodies against human cyclin B1 (cross-reacts with mouse, rat and human cyclin B1, all from Santa Cruz Biotechnology, Inc., Santa Cruz, USA, dilution 1:100) 

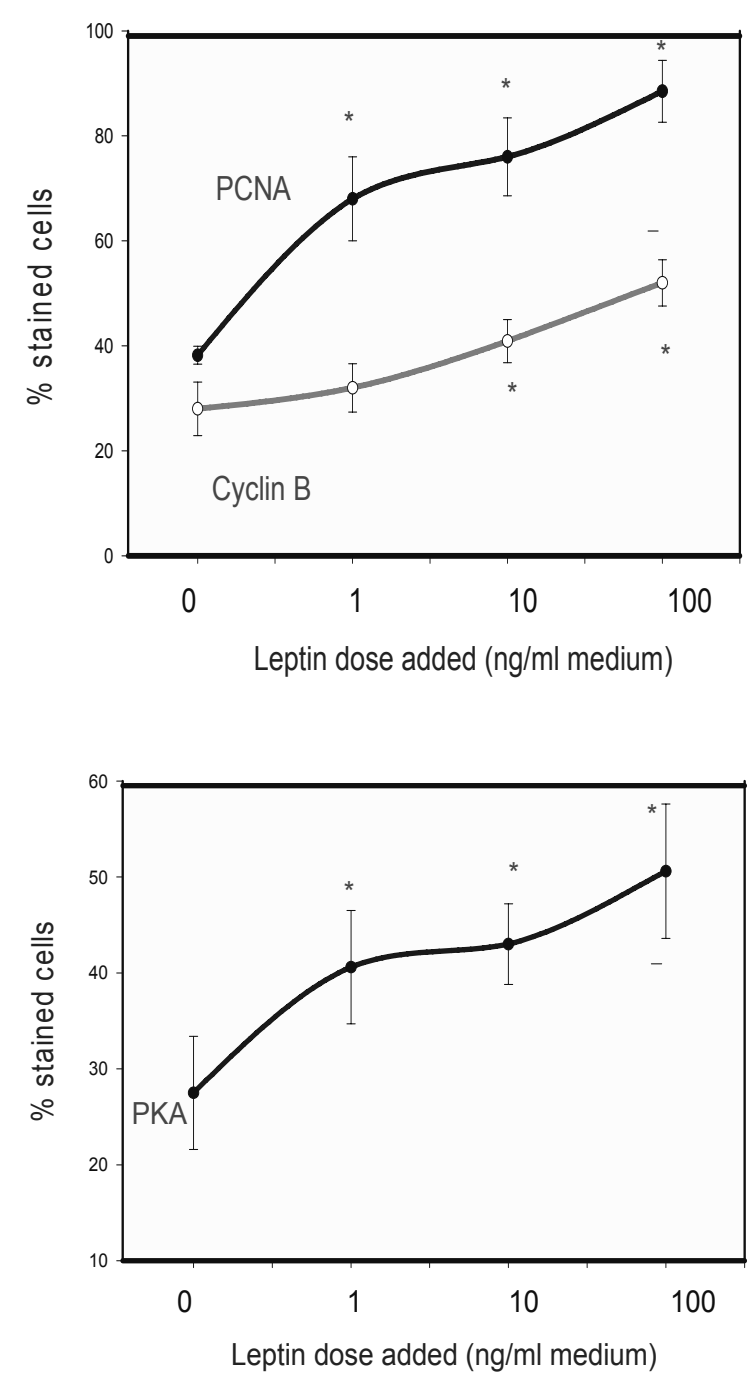

Fig. 1. Effect of leptin $(0,1,10$ or $100 \mathrm{ng} / \mathrm{ml})$ on the percentage of cultured human ovarian granulosa cells containing (a) PCNA, cyclin B1 and (b) protein kinase A (data from immunocytochemistry). Values are mean \pm SEM, *significant difference $(P<0.05)$ compared with control (medium without addition).

were used according to the instructions of the manufacturer. For the visualization of primary antibody, corresponding secondary antibody from ImmunoCruz Staining System or secondary polyclonal rabbit IgG labeled with horseradish peroxidase (Santa Cruz, dilution 1:1000 or Sevac, Prague, Czech Republic, dilution 1:2000) and DAB-reagent (Boehringer Mannheim $\mathrm{GmbH}$, Mannheim, Germany, $10 \%$ ) were used. The specificity of primary antibodies and molecular weights of ligands were confirmed prior to experiment by Western blotting (not shown). Cells treated with secondary antibody and DAB but omitting the primary antibody were used as negative controls. The presence of specific immunoreactivity in cells was determined by light microscopy.

\section{Bax}

23K-

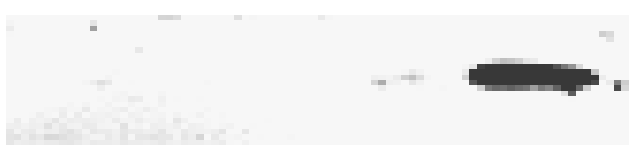

PKA

$47 \mathrm{~K}-$

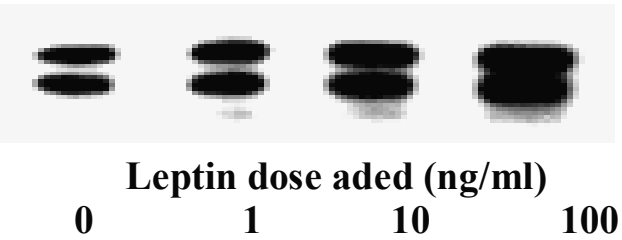

Fig. 2. SDS PAGE-Western immunoblots showing the effect of leptin $(0,1,10$ or $100 \mathrm{ng} / \mathrm{ml})$ on the expression of Bax (top) and protein kinase A (bottom). The fractions/subtances and their molecular weights $(k D)$ are marked to the left of the gel lanes.

\section{Protein gel electrophoresis and immunoblotting}

Lysates of granulosa cells were mixed 1:1 with electrophoretic buffer $(0.0625 \mathrm{M}$ Tris-base, $2 \%$ SDS, $10 \%$ glycerol, $0.5 \%$ 2-mercaptoethanol, $0.003 \%$ bromophenol blue, all from Sigma), boiled at $95{ }^{\circ} \mathrm{C}$ for $3 \mathrm{~min}$ and subjected to SDS-polyacrylamide gel electrophoresis in $4 \%$ and $10 \%$ stacking and resolving gels, respectively, at $25 \mathrm{~mA}$ constant current according to Laemmli (1970). The samples were then transferred to Porablot PVDF membranes (Macherey-Nagel, Duren, Germany) using a semi-dry transblotter (Bio-Rad Labs, Richmond, USA). Endogenous peroxidase in samples was quenched by incubation in $3 \% \mathrm{H}_{2} \mathrm{O}_{2}$ for $15 \mathrm{~min}$. Non-specific binding of antiserum was prevented by incubation in $5 \%$ blot-qualified BSA (Amersham) in TTBS (20 nM Tris-base, $137 \mathrm{nM} \mathrm{NaCl}, 0.1 \%$ Tween20). Blocked membranes were probed with rabbit polyclonal antibodies against the PKA (dilution 1:500) described above or against Bax (binds Bax of human, mouse and rat origin, dilution 1:250, both from Santa Cruz Biotechnology, Inc.). We failed to obtain the clear specific signal in Western blots using other antisera mentioned in chapter "Immunocytochemical analysis" of this manuscript. After treatment with primary antibody, membranes were incubated with secondary horseradish peroxidase-conjugated anti-rabbit IgG antibody (Sevac) and visualized using Super-Signal West-Pico luminescent substrate (Pierce, Rockford, Il, USA) and ECL Hyperfilm (Amersham plc, Little Clafton, UK). Incubation medium without cells was used as a negative control, beta-actin was used as positive control and control for equail loading (not shown). Molecular weights of fractions were evaluated using a molecular weight calibration kit $(18,24,45$, and $67 \mathrm{kD}$, ICN Biomedicals Inc, Irvine, CA, USA). 


\section{Statistics}

Each experimental group was represented by four culture wells or chambers. The proportions of cells containing specific immunoreactivity were calculated from inspection of at least 1000 cells per chamber. The data shown are mean values obtained in three separate experiments performed on separate days using separate pools of granulosa cells, each obtained from 4 women. The samples obtained in three experiments and intended for Western immunoblotting were pooled before electrophoresis Significant differences between groups in the proportion of cells containing specific immunoreactivity were evaluated by the Chi-square test. Differences from control at $\mathrm{P}<0.05$ level were considered as significant.

\section{Results}

Analysis of human granulosa cells and cellconditioned medium revealed detectable levels of PCNA, cyclin B1, Bax and PKA within the cells. Immunocytochemical analysis (Fig. 1) showed that the addition of leptin alone increased the percentage of cells containing PCNA (at 10 or $100 \mathrm{ng} / \mathrm{ml}$ ), cyclin (at 10 or $100 \mathrm{ng} / \mathrm{ml}$ ) and PKA (at 1, 10 or $100 \mathrm{ng} / \mathrm{ml}$ ). Western immunoblotting (Fig. 2) confirmed the concentrationdependent increase in accumulation of PKA in granulosa cells after leptin treatment. We also demonstrated the presence of visible Bax in the cells after leptin treatment (at 10 and $100 \mathrm{ng} / \mathrm{ml}$ ). Leptin effect on signaling molecules detected using either immunocytochemistry and Western immunoblotting was dose-dependent because the accumulation of all substances rose with leptin dose added.

\section{Discussion}

The present observations confirm the production of cell cycle- and apoptosis-associated peptides by human granulosa cells. The two bands of PKA detected in our experiments represent probably the catalytic and regulatory subunits of PKA detected using present antiserum against PKA (see Materials and Methods). Furthermore, our data demonstrate that leptin affected all the ovarian substances examined.

This is the first evidence for an involvement of leptin in the control of ovarian cell cycle proteins (PCNA and cyclin). Expression of PCNA and cyclin B is associated with rodent and human ovarian cell proliferation (Kadakia et al. 2001, Chaffin et al. 2001) and with the transition of rodent ovarian cells through late $\mathrm{G}_{1}$ and $\mathrm{S}$ phase of cell cycle (Naryzhny and Lee, 2001). Therefore, our data suggest a stimulatory effect of leptin on human ovarian cell proliferation via promotion of these phases of the cell cycle. This effect might induce ovarian follicular growth and development as described previously (Almog et al. 2001, Kikuchi et al. 2001) and/or promote granulosa cell luteinization, which is also associated with changes in cellular proliferation and cycle proteins (Murphy 2000).

The present stimulatory effect of leptin on Bax corresponds to the report of Almog et al. (2001) on leptin-induced expression of Bax in rat ovarian cells. This is the first demonstration of involvement of leptin in the control of human ovarian apoptosis.

The stimulatory effect of leptin on cell cycle proteins and apoptotic peptide suggests that leptin can control ovarian folliculogenesis and remodeling affecting both proliferation and apoptosis of ovarian cells and the equilibrium between these processes. The pattern of leptin influence on these processes suggests the gonadotropic role of leptin in human ovary. Although the data obtained during in vitro experiments should be extrapolated to in vivo conditions very carefully, our observations suggest the stimulatory role of leptin in human ovarian reproduction. These effects of leptin could explain the reported ovarian disturbances in animals and humans with altered leptin production or reception induced by obesity, malnutrition and genetic manipulations (Smith et al. 2001, Spicer 2001, Hamm et al. 2004).

An important role of PKA-dependent intracellular mechanisms in control of ovarian functions (Richards 2001), and the leptin-induced accumulation of PKA observed in our experiments provide the first evidence of the potential involvement of PKA in mediating leptin effects. The obtained results showed a potential new mechanism of leptin action on the ovary. This mechanism probably includes ovarian leptin receptors detected previously (Matsuoka et al. 1999, Duggal et al. 2002) and postreceptory intracellular PKA, the accumulation of which is induced by leptin, and which plays an important role in control of ovarian functions (Richards 2001, Murphy 2002). The interrelationship of PKA- and JAK/STAT-dependent intracellular mechanism of leptin action suggested previously (Matsuoka et al. 1999, Ruiz-Cortes et al. 2003) as well as the involvement of these mechanisms in 
human ovarian proliferation/apoptosis/remodeling detected during present experiment, require further studies.

Nevertheless, our observations 1) confirm the importance of leptin in control of apoptosis, 2) provide the first evidence for the involvement of leptin in control of ovarian cell cycle (S- and G-phase) and 3) suggest the PKA as potential leptin target and mediator of action on human ovarian cell functions. A better understanding of the effects of leptin and its mechanisms could be helpful in the discovery of links between reproduction, growth, and metabolism. Moreover, studies of described mechanism(s) of leptin action can be potentially useful for the detection and treatment of leptin-dependent metabolic and reproductive diseases.

\section{Conflict of Interest}

There is no conflict of interest.

\section{Acknowledgements}

The authors thank Dr AF Parlow (National Hormone and Pituitary Program, Harbor-UCLA Medical Center, Torrance, USA) for the gift of leptin, as well as Ing. J. Petrák, Ing. Ž Kuklová and Mrs K Tothová for technical assistance.

\section{References}

AGARWAL SK, VOGEL K, WEITSMAN SR, MAGOFFIN DA: Leptin antagonizes the insulin-like growth factor-I augmentation of steroidogenesis in granulosa and theca cells of the human ovary. J Clin Endocr Metab 84: 1072-1076, 1999.

ALMOG B, GOLD R, TAJMA K, DANTES A, SELIM K, RUBINSTEIN M, BARKAN D, HOMBURG R, LESSING JB, NEVO N, GERTLER A, AMSTERDAM A: Leptin attenuates follicular apoptosis and accelerates the onset of puberty in immature rats. Mol Cell Endocrinol 183: 179-191, 2001.

CHAFFIN CL, SCHWINOF KM, STOUFFER RL: Gonadotropin and steroid control of granulosa cell proliferation during the periovulatory interval in rhesus monkeys. Biol Reprod 65: 755-762, 2001.

DUGGAL PS, RYAN NK, VAN DER HOEK KH, RITTER LJ, ARMSTRONG DT, MAGOFFIN DA, NORMAN, RJ: Effect of leptin administration and feed restriction on thecal leucocytes in the preovulatory rat ovary and the effects of leptin on meiotic maturation, granulosa cell proliferation, steroid hormone and $\mathrm{PGE}_{2}$ secretion in cultured rat ovarian follicles. Reproduction 123: 891-898, 2002.

HAMM ML, BHAT GK, THOMPSON WE, MANN DR: Folliculogenesis is impaired and granulosa cell apoptosis is increased in leptin-deficient mice. Biol Reprod 71: 66-72, 2004.

HUANG H, CHEN D, ZHU Y, YANG X, JIN M, JI M: Study of effects of leptin on cultured human luteinized granulosa cell function (in Chinese) Zhonghua Fu Chan Ke Za Zhi. 37: 152-154, 2002.

KADAKIA R., ARRAZTOA JA, BONDY C, ZHOU J: Granulosa cell proliferation is impaired in the IGF-1 null ovary. Growth Horm. IGF Res 11: 220-224, 2001.

KIKUCHI N, ANDOH K, ABE Y, YAMADA K, MIZUMA H, IBUKI Y: Inhibitory action of leptin on early follicular growth differs in immature and adult female mice. Biol Reprod 65: 66-71, 2001.

KITAWAKI J, KUSUKI I, KOSHIBA H, TSUKAMOTO K, HONJO H: Leptin directly stimulates aromatase activity in human luteinized granulosa cells. Mol Hum Reprod 5: 708-713, 1999.

MATSUOKA T, TAHARA M, YOKOI T, MASUMOTO N, TAKEDA T, YAMAGUCHI M, TASAKA K, KURACHI H, MURATA Y: Tyrosine phosphorylation of STAT3 by leptin through leptin receptor in mouse metaphase 2 stage oocyte. Biochem Biophys Res Commun 256: 480-484, 1999.

MURPHY BD: Models of luteinization. Biol Reprod 63: 2-11, 2002.

NARYZHNY SN, LEE H: Protein profiles of the Chinese hamster ovary cells in the resting and proliferating stages. Electrophoresis 22: 1764-1775, 2001.

OSBORN M, ISENBERG S: Immunocytochemistry of frozen and paraffin tissue sections. In: Cell Biology. A Laboratory Handbook Vol. 2, CELIS JE (ed), New York, Academic Press, 1994, pp. 361-367.

RICHARDS JC: New signalling pathways for hormones and cyclic 3', 5'-monophosphate action on endocrine cells. Mol Endocrinol 15: 209-218, 2001.

RUIZ-CORTES ZT, MARTEL-KENNES Y, GEVRY NY, DOWNEY BR, PALIN MF, MURPHY BD: Biphasic effects of leptin in porcine granulosa cells. Biol Reprod 68: 789-796, 2003. 
SMITH GD, JACKSON LM, FOSTER DL: Leptin regulation of reproductive function and fertility. Theriogenology $\mathbf{5 7}$ : 73-86, 2001.

SPICER LJ: Leptin: a possible metabolic signal affecting reproduction. Dom Anim Endocrinol 21: 251-270, 2001.

SPICER LJ, CHAMBERLAIN CS, FRANCISCO CC: Ovarian action of leptin: effects on insulin-like growth factor-Istimulated function of granulosa and thecal cells. Endocrine 12: 53-59, 2000.

SIROTKIN AV, MLYNCEK M, KOTWICA J, MAKAREVICH AV, FLORKOVICOVA I, HETENYI L: Leptin directly controls secretory activity of human ovarian granulose cells: possible inter-relationship with IGF/IGFBP system. Hormone Res 64: 198-202, 2005. 